\title{
PENGARUH MEDIA GOOGLE EARTH TERHADAP HASIL BELAJAR BERDASARKAN KEAKTIFAN SISWA KELAS IV TEMA INDAHNYA NEGERIKU DI SEKOLAH DASAR
}

\author{
Aldoko Listiaji Putra ${ }^{1}$, Aminuddin Kasdi ${ }^{2}$, Waspodo Tjipto Subroto ${ }^{3}$ \\ ${ }^{1}$ Mahasiswa Program Pascasarjana, Prodi Pendidikan Dasar, Universitas Negeri Surabaya, \\ ${ }^{2 \& 3}$ Dosen Pascasarjana, Prodi Pendidikan Dasar, Universitas Negeri Surabaya \\ e-mail: aldokolp@gmail.com ${ }^{1}, \underline{\text { aminuddinkasdi@unesa.ac.id }}{ }^{2}, \underline{\text { waspodosubroto@ } \text { unesa.ac.id }^{3}}$
}

\section{Received : Juli 2019}

Reviewed: Agustus 2019

Accepted : September 2019

Published : September 2019

\section{ABSTRACT}

The main purpose of this research is: 1) to describe the effect of the google earth media to student learning outcomes, 2) to describe the effect of student activeness to student learning outcomes, 3) to describe the interaction effects between google earth media and student activeness to student learning outcomes. This research was conducted at SDN Lidah Kulon 1 Surabaya with research subjects are students of Fourth Grade Student B as the control class and Fourth Grade Student $C$ as an experimental class of the school year 2015/2016. Type of research is experimental. The data was obtained as follows: (1) there is the effect of the google earth media to student learning outcomes. With the same test two way of anova significance value the effect cognitive ability level of $0.002<0.05$, (2) there is a activeness the effect to student learning outcomes. This conclusion is drawn from the results of empirical tests using two way of anova. With the test results show the value of the activity's significant the effect to student learning outcomes of 0,023<0,05, (3) there is no interaction effect of media and activeness to student learning outcomes. This conclusion is drawn based on two way of anova showed significant value interaction effect of media and activeness to student learning outcomes of 0.547>0.05. Based on the research, it can be concluded that: (1) google earth media have a significant effect to the learning outcomes of students, (2) activeness have a significant effect to the learning outcomes of students, (3) there is no significant effect from the interaction between the media and the activeness to student learning outcomes.

Keywords: Google Earth, Activeness, Learning Outcomes.

\section{ABSTRAK}

Tujuan utama penelitian ini adalah: 1) untuk mendeskripsikan pengaruh media google earth terhadap hasil belajar siswa, 2) untuk mendeskripsikan pengaruh keaktifan siswa terhadap hasil belajar siswa, 3) untuk mendeskripsikan pengaruh interaksi antara media google earth dan keaktifan siswa terhadap hasil belajar siswa. Penelitian ini dilakukan di SDN Lidah Kulon 1 Surabaya dengan subjek penelitian adalah siswa kelas IV B sebagai kelas kontrol dan IV C sebagai kelas eksperimen tahun pelajaran 2015/2016. Jenis penelitian yang dilakukan adalah penelitian eksperimen. Data hasil penelitian yang diperoleh sebagai berikut: 1) terdapat pengaruh media google earth terhadap hasil belajar siswa. Dengan uji yang sama yakni uji anava dua jalur diperoleh nilai signifikansi pengaruh tingkat kemampuan kognitif sebesar 0,002 <0,05, 2) terdapat pengaruh keaktifan terhadap hasil belajar siswa. Kesimpulan ini diambil mengacu pada hasil uji empiris menggunakan anava dua jalur. Dengan hasil uji menunjukan nilai signifikansi pengaruh keaktifan terhadap hasil belajar siswa sebesar 0,023<0,05, 3) tidak terdapat pengaruh interaksi keaktifan dan media terhadap hasil belajar siswa. Kesimpulan ini diambil berdasarkan hasil uji anava dua jalur yang menunjukan nilai signifikansi pengaruh interaksi media dan keaktifan terhadap hasil belajar siswa sebesar 0,547>0,05. Berdasarkan hasil penelitian, dapat disimpulkan bahwa: 1) media google earth terhadap hasil belajar siswa menunjukan terdapat pengaruh yang signifikan, 2) keaktifan terhadap hasil belajar siswa menunjukan terdapat 
pengaruh signifikan, 3) interaksi antara media dan keaktifan tidak memiliki pengaruh signifikan terhadap hasil belajar siswa.

Kata Kunci : Google Earth, Keaktifan, Hasil Belajar.

\section{PENDAHULUAN}

Pendidikan bertujuan untuk mempersiapkan sumber daya manusia yang berkualitas dan mampu untuk bersaing di era global. Salah satu upaya yang dilakukan Indonesia untuk tercapainya tujuan pendidikan adalah dengan memperbaiki kurikulum setiap 5 tahun. Kurikulum yang diterapkan saat ini adalah Kurikulum 2013 yang merupakan kelanjutan dari pengembangan Kurikulum Berbasis Kompetensi yang telah dirintis pada tahun 2004 dan Kurikulum Tingkat Satuan Pendidikan pada tahun 2006 (Kemendikbud, 2014).

Permasalahan pendidikan selalu muncul bersamaan dengan berkembang dan meningkatnya kemampuan siswa, situasi dan kondisi lingkungan yang ada, pengaruh informasi dan kebudayaan, serta berkembangnya ilmu pengetahuan dan teknologi. Pendidikan adalah komunikasi, karena dalam proses pendidikan terdapat komunikator, komunikan, dan pesan (message), yakni sebagai komponen-komponen komunikasi (Munadi, 2013:2).

Perkembangan teknologi informasi telah memasuki berbagai sendi kehidupan, termasuk dunia pendidian lebih khususnya pembelajaran telah diintervensi oleh keberadaan teknologi ini. Seiring dengan perkembangan aplikasi teknologi informasi dalam dunia pendidikan, maka berbagai bahan pembelajaranpun telah diproduksi dan dikonsumsi oleh pembelajar melalui medium teknologi informasi dalam bentuk kemasan yang sangat bervariasi. Berbeda dengan proses pembelajaran tradisional yang mengandalkan guru sebagai sumber belajar yang pertama dan utama sedangkan sumber lain hanyalah pelengkap kegiatan pembelajaran (Sa'ud, 2008:179-180).

Selama ini telah mengenal bahkan menggunakan beberapa bentuk teknologi pendidikan untuk membantu kegiatan-kegiatan pembelajaran. Beberapa alat tersebut misalnya OHP, LCD, Projector, penggunaan komputer, dan beberapa bentuk peralatan laboratorium. Munculnya alat bantu dalam teknologi pendidikan tersebut membawa nuansa baru dalam terutama dalam pelaksanaan proses pembelajaran. Sambutan masyarakat para pengguna teknologi pendidikan sangat besar, sehingga dalam waktu yang tidak terlalu lama teknologi ini sudah begitu familiar dalam membantu kelancaran pelaksanaan pendidikan dan pembelajaran.

Perkembangan teknologi yang demikian pesat, terutama teknologi komunikasi membawa perubahan besar dalam berbagai bidang. Salah satu bidang yang juga berkembang sebagai akibat kemajuan teknologi komunikasi ini adalah bidang pendidikan dan pembelajaran. Jika waktu-waktu sebelumnya hubungan antara pendidik - peserta didik hanya berlangsung melalui kegiatan tatap muka, dibatasi oleh sekat ruang dan waktu, atau melalui media cetak, ternyata saat ini telah dapat dikembangkan melalui komunikasi online yang menembus sekat-sekat ruang dan waktu. Melalui media elektronik ini, disamping banyak nilai tambah atau katakanlah "keunggulan" atau kelebihan, dari dimensi pedagogis tentu banyak faktor yang patut dicermati, misalnya bagaimana pergeseran pola komunikasi edukatif antara guru dan siswa, bagaimana dengan teknik-teknik belajar mengajar, bagaimana dengan pemahaman peserta didik, dan beberapa aspek psikologi belajar lainnya (Dimyati \& Mudjiono, 2009:229-230).

Revolusi ilmu pengetahuan dan teknologi, perubahan masyarakat pemahaman cara belajar anak, kemajuan media komunikasi dan lainnya sebagainya member arti sendiri bagi kegiatan pendidikan dan tuntutan inilah yang membuat kebijaksanaan untuk memanfaatkan media teknologi dan pendekatan teknologi dalam pengelolaan pendidikan. Pendidikan sebagai bagian dari kebudayaan merupakan sarana penerus nilai-nilai, gagasangagasan, sehingga setiap orang mampu berperan serta dalam transformasi nilai demi kemajuan bangsa dan Negara. Ini berarti bahwa pendidikan adalah wadah untuk mentransformasikan ilmu pengetahuan dan teknologi demi kepentingan kehidupan manusia.

Pemanfaatan teknologi komunikasi untuk kegiatan pendidikan, teknologi pendidikan serta media pendidikan diperlukan dalam rangka kegiatan belajar mengajar. Karena dengan pendekatan ilmiah, sistematis dan rasional, sebagaimana dituntut oleh teknologi pendidikan ini pulalah, tujuan pendidikan yang efektif dan efisien akan tercapai.

Kondisi pembelajaran di Sekolah Dasar yang ditemukan masih terpaku pada penguasaan aspek pengetahuan. Suasana kelas yang tergambarkan juga masih kurang efektif dan efisien untuk melakukan proses pembelajaran, karena masih banyak siswa yang ramai sendiri dan bukan ramai karena mendiskusikan materi pelajaran yang sedang disampaikan. Ketika diminta untuk menanggapi permasalahan atau mendiskusikan materi yang 
disampaikan, banyak siswa yang masih pasif dalam menyampaikan pendapatnya. Siswa cenderung hanya duduk, mendengarkan, dan mencatat apa yang disampaikan oleh guru dan banyaknya siswa yang kurang tergerak aktif untuk mencari informasi sendiri dari sumber lain.

Pandangan guru menjadikan aspek kognitif menjadi hal utama yang harus dikuasai siswa dalam pembelajaran cenderung akan sedikit sekali melibatkan siswa dalam kemandiriannya untuk memperoleh pembelajaran. Bukan suatu pengetahuan yang bisa dipindahkan begitu saja dari guru kepada siswanya, perlu pembiasaan secara aktif dalam pembelajaran yang melibatkan siswa memperoleh pengetahuan yang sama bahkan lebih dari pengetahuan yang dimiliki gurunya. Pada pembelajaran guru hanya menjelaskan materi secara konseptual yaitu menjelaskan materi berdasarkan konsep-konsepnya saja tanpa mengaitkan materi dengan kehidupan sehari-hari siswa.

Dalam kondisi pembelajaran, terlihat siswa masih banyak pasif dalam penguasaan materi yang sudah disampaikan. Ketika guru meminta siswa untuk mengajukan pertanyaan permasalahan dalam pembelajaran, siswa masih banyak pasif (diam dan bingung mencari pertanyaan dari buku teks). Dalam kegiatan berkelompok, banyak ditemukan siswa yang hanya menggantungkan diri kepada temannya saat mengerjakan tugas yang diberikan oleh guru dan belum terlihat keaktifan siswa dalam berpendapat atau menanggapi permasalahan yang sudah disampaikan.

Dalam konteks yang lebih luas, teknologi informasikan komunikasi merangkum semua aspek yang berhubungan dengan mesin (Komputer dan telekomunikasi) dan teknik yang digunakan untuk menangkap (mengumpulkan), menyimpan, memanipulasi, dan mengantarkan. Komputer yang mengendalikan semua bentuk ide dan informasi memainkan peranan penting. Pengumpulan, pemrosesan, penyimpanan dan penyebaran informasi suara, gambar, teks dan nomor pleh gabungan pengkomputeran dan telekomunikasi yang berasakan mikroelektronik. Teknologi informasi dan komunikasi menggabungkan bidang teknologi secara pengkomputeran. Telekomunikasi dan elektronik dan bidang informasi seperti data, fakta dan proses (Munir, 2009:30-31).

Bila seseorang mau belajar terus sepanjang hidupnya, maka pelajaran di sekolah harus merupakan pengalaman yang menyenangkan baginya. Belajar adalah suatu proses usaha yang dilakukan seseorang untuk memperoleh suatu perubahan tingkah laku yang baru secara keseluruhan, sebagai hasil pengalamannya sendiri dalam interaksi dengan lingkungannya (Daryanto, 2010:2).
Menurut Djamarah (2008:13) bahwa belajar adalah serangkaian kegiatan jiwa raga untuk memperoleh suatu perubahan tingkah laku sebagai hasil dari pengalaman individu dalam interaksi dengan lingkungannya yang menyangkut kognitif, afektif, dan psikomotor.

Belajar merupakan suatu proses perubahan yaitu perubahan tingkah laku sebagai hasil dari interaksi dengan lingkungannya dalam memenuhi kebutuhan hidupnya (Slameto, 2010:2)

Belajar adalah tahapan perubahan seluruh tingkah laku individu yang relatif menetap sebagai hasil pengalaman dan interaksi dengan lingkungan yang melibatkan proses kognitif (Syah, 2010:90).

Belajar merupakan perubahan perilaku seseorang melalui latihan dan pengalaman, seseorang belajar tidak ditentukan oleh kekuatan-kekuatan yang datang dari dalam dirinya atau oleh stimulus-stimulus yang datang dari lingkungan, akan tetapi merupakan interaksi timbal balik dari determi-determi individu dan determi-determi lingkungan (Yamin, 2007:168).

Menurut Hamalik (2011:27) Belajar merupakan suatu proses, suatu kegiatan, dan bukan suatu hasil atau tujuan. Sedangkan menurut Purwanto (2011:38) belajar adalah proses dalam diri individu yang berinteraksi dengan lingkungan untuk mendapatkan perubahan dalam perilaku.

Murid yang frustasi sering mendapat nilai rendah disamping teguran, kecaman dan celaan akan benci terhadap segala bentuk pelajaran formal dan tidak cukup mempunyai motivasi untuk melanjutkan pelajarannya. Sehingga, sebagian besar yang mendapat nilai rendah dan mengalami frustasi akan berhenti belajar dan tidak mengembangkan bakat yang dapat disumbangkan kepada masyarakat.

Dalam penelitian ini, peneliti akan menggunakan google earth sebagai media pembelajaran. Peneliti memilih SDN Lidah Kulon I Surabaya sebagai tempat penelitian karena SDN Lidah Kulon I Surabaya salah satu sekolah yang jumlah muridnya banyak dan masih sedikit familiernya guru dalam penggunaan teknologi informasi dan komunikasi terutama internet. Dengan penggunaan aplikasi google earth diharapkan akan meningkatkan penggunaan sarana pembelajaran yang lebih baik sehingga meningkatkan pemahaman siswa terhadap materi pelajaran yang berdampak pada meningkatnya hasil belajar.

Dari pemaparan diatas, peneliti ingin mencoba dan mengetahui melalui cara yang efektif dan efisien guna mencapai tujuan pendidikan yang telah ditentukan dan pembelajaran siswa dapat menguasai secara penuh terhadap seluruh bahan yang sudah dipelajari. Sehingga peneliti memberikan judul pada penelitian ini dengan 
"Pengaruh Media Google Earth Terhadap Hasil Belajar Berdasarkan Keaktifan Siswa Kelas IV Tema Indahnya Negeriku di Sekolah Dasar”.

\section{METODE}

Jenis penelitian yang digunakan dalam penelitian dengan judul "Pengaruh Media Google Earth Terhadap Hasil Belajar Berdasarkan Keaktifan Siswa Kelas IV Tema Indahnya Negeriku di Sekolah Dasar" adalah jenis penelitian eksperimen. Dimana dalam penelitian ini terdapat dua variabel, yaitu variabel terikat dan variabel bebas.

Jenis penelitian kuantitatif yang akan dilaksanakan adalah jenis penelitian eksperimen karena bertujuan untuk mengukur pengaruh variabel bebas yaitu penggunakan Google earth dan keaktifan siswa terhadap variabel terikat yaitu hasil belajar.

Tabel 1. Instrumen Penelitian

\begin{tabular}{ccc}
\hline Keaktifan & \multicolumn{2}{c}{ Media } \\
& $\begin{array}{c}\text { Google earth } \\
(\mathbf{B} 1)\end{array}$ & $\begin{array}{c}\text { Konvensional } \\
\left(\mathbf{B}_{2}\right)\end{array}$ \\
$\begin{array}{c}\text { Rendah } \\
\left(\mathbf{A}_{1}\right)\end{array}$ & & \\
\hline Tinggi & & \\
$\left(\mathbf{A}_{2}\right)$ & & \\
\hline Hasil & & \\
\hline
\end{tabular}

Metode penelitian yang digunakan dalam penelitian ini adalah metode eksperimen. Sampel terdiri dari dua kelas berbeda yang nantinya akan mendapatkan pembelajaran dengan media yang berbeda. Kelas eksperimen akan mendapat media Google Earth dan kelas kontrol akan belajar dengan media konvensional.

Penelitian ini adalah eksperimen. Bentuk desain eksperimen ini peneliti dapat mengontrol semua variabel luar yang mempengaruhi jalannya pelaksanaan eksperimen. Desain penelitian menggunakan desain Posttest-only Control Group Design atau yang disebut juga Desain Kelompok Kontrol dengan Tes Akhir Saja Dalam penelitian ini, peneliti membandingkan dua kelompok penelitian. Satu kelompok siswa yaitu yang diberi perlakuan khusus sebagai kelas eksperiment berupa penggunaan media google earth, sedangkan satu kelompok siswa lagi yaitu sebagai kelas kontrol dimana dalam proses belajar mengajar menggunakan media konvensional.

Tabel 2 Desain Penelitian

\begin{tabular}{ccc}
\hline Kelompok & Perlakuan & Hasil Belajar \\
E & $\mathrm{X}$ & $\mathrm{O}$ \\
$\mathrm{C}$ & & $\mathrm{O}$ \\
\hline
\end{tabular}

\section{Keterangan}

E : Kelompok eksperimen

C : Kelompok kontrol

$\mathrm{X}$ : Penggunaan media Google Earth dalam pembelajaran pada kelompok eksperimen.

$O \quad$ : Hasil Belajar yang diberikan kepada kedua kelompok

Simbol X menunjukan variabel eksperimental dalam hal ini adalah media google earth. Simbol O mewakili observasi yang dilakukan untuk memperoleh data dari objek yang diteliti tentang pengaruh yang diberikan oleh variabel eksperimental,

Pada kelompok eksperimen pembelajaran dilakukan dengan menggunakan media google earth, sedangkan pada kelompok kontrol pembelajaran dilakukan dengan menggunakan media konvensional.

Subjek penelitian ini adalah siswa kelas IV-B dan IV-C SDN Lidah Kulon I Surabaya. Sampel penelitian adalah 40 untuk masuk kelas kontrol dan 39 siswa untuk masuk kelas eksperimen. Waktu penelitian akan dilakukan pada semester genap tahun pelajaran 2015/ 2016.

Validitas merupakan suatu ukuran yang menunjukkan tingkat-tingkat kevalidan atau kesahihan suatu instrumen. Suatu instrumen yang valid akan mempunyai validitas tinggi dan sebaliknya instrumen yang kurang valid berarti memiliki validitas rendah. Rumus korelasi yang dapat digunakan adalah yang dikemukakan oleh Pearson, yang dikenal dengan rumus korelasi product moment, sebagai berikut:

$$
r_{x y}=\frac{\mathrm{N} \sum X Y-\left(\sum X\right)\left(\sum \mathrm{Y}\right)}{\sqrt{\left\{N \sum X^{2}-\left(\sum X\right)^{2}\right\}\left\{N \sum Y^{2}-\left(\sum Y\right)^{2}\right\}}}
$$

(Winarsunu, 2009:242)

Keterangan :

$\mathrm{r}_{\mathrm{xy}} \quad$ : Validitas butir soal

N $\sum X Y$ : Skor tes pada butir soal yang dicari validitasnya

$\sum \mathrm{X} \quad$ : Skor soal yang dicapai tes

$\sum \mathrm{Y}$ : Jumlah peserta tes

Kriteria : Jika $r_{\text {hitung }}>r_{\text {tabel }}$ maka item soal dikatakan valid

Uji reliabilitas dilakukan untuk menguji ketetapan suatu tes apabila diujikan kembali pada subyek yang sama. Artinya apabila diujikan kembali pada siswa maka hasilnya tidak akan jauh berbeda. Sehingga dapat dikatakan hasil penilaian terhadap indikator yang diukur bersifat reliable atau dapat dipercaya. Untuk mengetahui reliabilitas instrumen digunakan rumus Alpha Cronbach sebagai berikut: 


$$
r_{11}=\left(\frac{n}{n-1}\right) \cdot\left(1-\frac{\sum \sigma_{i}^{2}}{\sigma_{t}^{2}}\right)
$$

(Arikunto, 2013:109)

Keterangan:

$r_{11} \quad$ :Reliabilitas yang dicari

n : Banyaknya butir soal

$\sigma_{i}^{2} \quad$ : Varians tiap soal

$\sigma_{t}^{2} \quad:$ Varians total

Kriteria Klasifikasi Reliabilitas

$0,800-1,000$ : Sangat Tinggi

$0,600-0,800:$ Tinggi

0,400 - 0,600 : Cukup

$0,200-0,400:$ Rendah

$0,000-0,200$ : Sangat Rendah

(Arikunto, 2013:75)

Uji normalitas dilakukan untuk mengetahui apakah data hasil penelitian berdistribusi normal atau tidak. Data yang berdistribusi normal apabila dibuat dalam bentuk kurva akan menghasilkan kurva normal. Pengujian normalitas data hasil penelitian dengan menggunakan uji Shapiro-Wilk (uji W) dengan bantuan software SPSS.

Adapun beberapa rumus yang digunakan dalam uji Shapiro-Wilk ini yaitu :

a. Pembagi (d) uji W :

$d=\sum_{i=1}^{n}\left(x_{i}-\bar{x}\right)^{2}=\sum_{i=1}^{n} x_{i}^{2}-\frac{1}{n}\left(\sum_{i=1}^{n} x_{i}\right)^{2}$

$\mathrm{n}$ : jumlah data yang akan di ujikan

b. Pembatas (k) uji W :

$\begin{aligned} \text { Jika n genap } \quad k & =\frac{n}{2} \\ \text { Jika n ganjil } & =\frac{n-1}{2}\end{aligned}$

c. Rumus $\mathrm{W}_{\text {hitung }}(\mathrm{W})$ :

$$
W=\frac{1}{d}\left[\sum_{i=1}^{k} a_{i}\left(x_{[n-i+1]}-x_{[i]}\right)\right]^{2}
$$

Nilai d berasal dari perhitungan rumus yang pertama. Nilai batas sigma (k) berasal dari perhitungan rumus yang kedua.

Seperti halnya uji normalitas lainnya uji ShapiroWilk ini juga memiliki 2 buah hipotesis yang diujikan, yaitu :
$\mathrm{H}_{0} \quad$ : Sampel berasal dari populasi yang berdistribusi normal

$\mathrm{H}_{1} \quad$ : Sampel berasal dari populasi yang tidak berdistribusi normal

Kriteria pengujian yang digunakan dalam uji Shapiro-Wilk ini adalah apabila nilai $\mathrm{W}_{\text {hitung }} \leq 0,05$ maka data dikatakan tidak berdistribusi normal $\left(\mathrm{H}_{0}\right.$ ditolak). Sebaliknya apabila nilai $\mathrm{W}_{\text {hitung }}>0,05$ maka data dikatakan berdistribusi normal $\left(\mathrm{H}_{0}\right.$ diterima).

Uji homogenitas varians dilakukan untuk mengetahui apakah kedua kelompok sampel memiliki kesamaan karakteristik (homogen) atau tidak. Dalam penelitian ini, pengujian homogenitas menggunakan uji Levene. Pemilihan uji Levene berdasar pada desain penelitian yang memunculkan data dengan jumlah kelompok lebih dari dua. Penghitungan uji Levene dalam penelitian ini dilakukan dengan bantuan software SPSS. Adapun rumus yang digunakan dalam uji Levene ini adalah sebagai berikut :

$$
W=\frac{(N-k)}{(k-1)} \frac{\sum_{i=1}^{k} N_{i}\left(Z_{i \cdot}-Z . .\right)^{2}}{\sum_{i=1}^{k} \sum_{j=1}^{N_{i}}\left(Z_{i j}-Z_{i .}\right)^{2}},
$$

Adapun pasangan hipotesis yang akan diuji adalah sebagai berikut:

$\mathrm{H}_{0}$ : Kelompok sampel berasal dari populasi yang mempunyai varians sama atau homogen

$\mathrm{H}_{1}$ : Kelompok sampel berasal dari populasi yang mempunyai varians berbeda atau tidak homogen

Kriteria pengujian yang digunakan dalam uji Levene ini adalah apabila nilai $\mathrm{W}_{\text {hitung }} \leq 0,05$ maka kelompok data dikatakan memiliki varians yang tidak homogen $\left(\mathrm{H}_{0}\right.$ ditolak). Sebaliknya apabila nilai $\mathrm{W}_{\text {hitung }}>0,05$ maka kelompok data dikatakan memiliki varians yang homogen $\left(\mathrm{H}_{0}\right.$ diterima). Dengan desain dan hasil penelitian yang diperoleh akan dicari nilai homogenitas bersama yang melibatkan empat kelompok data sekaligus.

Anava faktorial atau sering juga disebut anava ganda adalah teknik statistik parametrik yang digunakan untuk menguji perbedaan antara kelompok-kelompok data yang berasak dari 2 variabel bebas atau lebih (Winarsunu, 2009:107)

Untuk melakukan pengujian hipotesis dengan menggunakan ANAVA 2 jalur, langkah-langkah yang harus dilakukan adalah:

a. Menghitung Jumlah kuadrat total $\left(\mathrm{JK}_{\mathrm{t}}\right)$, Antar A $\left(\mathrm{Jk}_{\mathrm{A}}\right)$, Antar B $\left(\mathrm{Jk}_{\mathrm{B}}\right)$, Interaksi A x B $\left(\mathrm{Jk}_{\mathrm{AB}}\right)$, dan Dalam kelompok $\left(\mathrm{Jk}_{\mathrm{d}}\right)$, dengan formula sebagai berikut. 


$$
\begin{aligned}
\mathrm{JK}_{\mathrm{t}} & =\sum X_{t}^{2}-\frac{\left(X_{t}\right)^{2}}{N} \\
\mathrm{JK}_{\mathrm{A}} & =\left[\frac{\left(\sum X_{A 1}\right)^{2}}{n_{A 1}}+\frac{\left(\sum X_{A 2}\right)^{2}}{n_{A 2}}\right] \\
\mathrm{JK}_{\mathrm{B}} & =\left[\frac{\left(\sum X_{B 1}\right)^{2}}{n_{B 1}}+\frac{\left(\sum X_{B 2}\right)^{2}}{n_{B 2}}+\frac{\left(\sum X_{B 3}\right)^{2}}{n_{B 3}}\right]-S k \\
\mathrm{JK}_{\mathrm{AB}} & =\left[\frac{\left(\sum X_{A B}\right)^{2}}{n_{A B}}\right]-S k-\left(\mathrm{JK}_{\mathrm{A}}+\mathrm{JK}_{\mathrm{B}}\right) \\
\mathrm{JK}_{\mathrm{d}} & =\mathrm{JK}_{\mathrm{t}}-\left(\mathrm{JK}_{\mathrm{A}}+\mathrm{JK}_{\mathrm{B}}+\mathrm{JK}_{\mathrm{AB}}\right)
\end{aligned}
$$

(Winarsunu, 2009:108)

b. Menghitung derajat kebebasan total $\left(\mathrm{db}_{\mathrm{t}}\right)$, antar $A\left(d_{A}\right)$, antar $B\left(d_{B}\right)$, interaksi A x B $\left(d^{A B}\right)$, dan dalam kelompok $\left(\mathrm{db}_{\mathrm{d}}\right) \mathrm{db}_{\mathrm{t}}=\mathrm{N}-1, \mathrm{db}_{\mathrm{A}}=\mathrm{K}$ $-1, \mathrm{db}_{\mathrm{B}}=\mathrm{K}-1, \mathrm{db}_{\mathrm{AB}}=\mathrm{db}_{\mathrm{A}} \mathrm{X} \mathrm{db}_{\mathrm{B}} \mathrm{db}_{\mathrm{d}}=\mathrm{db}_{\mathrm{t}}-$ $\left(\mathrm{db}_{\mathrm{A}}+\mathrm{db}_{\mathrm{B}}+\mathrm{db}_{\mathrm{AB}}\right)$

c. Menghitung rata-rata kuadrat antar $A\left(\mathrm{Rk}_{\mathrm{A}}\right)$, antar $\mathrm{B}\left(\mathrm{Rk}_{\mathrm{B}}\right)$, interaksi A x B $\left(\mathrm{Rk}_{\mathrm{AB}}\right)$, dan dalam kelompok $\left(\mathrm{Rk}_{\mathrm{D}}\right)$

$$
\begin{array}{ll}
\mathrm{Rk}_{\mathrm{A}}=\frac{J k_{A}}{d b_{A},} & \mathrm{Rk}_{\mathrm{B}}=\frac{J k_{B}}{d b_{B}} \\
\mathrm{Rk}_{\mathrm{AB}}=\frac{J k_{A B}}{d b_{A B}}, & \mathrm{Rk}_{\mathrm{D}}=\frac{J k_{D}}{d b_{D}}
\end{array}
$$

d. Menghitung rasio $\mathrm{F}_{\mathrm{A}}, \mathrm{F}_{\mathrm{B}}, \mathrm{F}_{\mathrm{AB}}$

$$
\mathrm{F}_{\mathrm{A}}=\frac{R k_{A}}{R k_{d}}, \mathrm{~F}_{\mathrm{B}}=\frac{R k_{B}}{R k_{d}}, \text { dan } \mathrm{F}_{\mathrm{AB}}=\frac{R k_{A B}}{R k_{d}}
$$

Kriteria pengujian, jika $F_{\text {hitung }}>F_{\text {tabel }}$ pada taraf signifikan yang dipilih dengan $\mathrm{db}$ pembilang adalah $\mathrm{db}$ yang sesuai, maka $\mathrm{H}_{0}$ ditolak. Jadi terdapat perbedaan ratarata antara kelompok-kelompok yang diuji, sebaliknya untuk $\mathrm{F}_{\text {hitung }} \leq \mathrm{F}_{\text {tabel }}$, maka $\mathrm{H}_{0}$ diterima. Untuk ANAVA 2 jalur, langkah pertama yang dilakukan adalah melakukan pengujian terhadap hipotesis statistik pengaruh interaksi, yaitu $\mathrm{F}_{(\mathrm{OAB})}$. Jika $\mathrm{F}_{(\mathrm{OAB})} \leq \mathrm{F}_{\text {tabel }}$ atau $\mathrm{H}_{0}$ diterima berarti tidak terdapat pengaruh interaksi, maka selanjutnya dilakukan uji hipotesis pengaruh utama (main effect), yaitu uji $\mathrm{F}_{(\mathrm{OA})}$ untuk melihat perbedaan rerata antar $\mathrm{A}$, dan uji $\mathrm{F}_{(\mathrm{OB})}$ untuk mempelajari perbedaan antar B. Sebaliknya jika $\mathrm{F}_{(\mathrm{OAB})}>\mathrm{F}_{\text {tabel }}$ atau $\mathrm{H}_{0}$ ditolak, berarti terdapat pengaruh interaksi yang signifikan, maka konsekuensinya harus diuji pengaruh sederhana (simple effect). Simple effect adalah perbedaan rerata antar $\mathrm{A}$ pada tiap kelompok $\mathrm{B}_{\mathrm{i}}(\mathrm{i}=$ $1,2,3, \ldots$ ) atau perbedaan rerata antar B pada tiap kelompok $\mathrm{A}_{\mathrm{i}}(\mathrm{i}=1,2,3, \ldots)$ (Kadir, 2010: 216).

\section{HASIL DAN PEMBAHASAN}

Penelitian dilakukan di kelas IV SDN Lidah Kulon I Surabaya. Dengan kelas IV C ditetapkan sebagai kelas eksperimen dan kelas IV B sebagai kelas kontrol. Sampel dalam penelitian ini berjumlah 79 siswa, 39 siswa kelas eksperimen dan 40 siswa kelas kontrol. Siswa kelas eksperimen belajar dengan menggunakan media Google Earth sementara kelas kontrol belajar dengan menggunakan media konvensional.

Kelompok siswa ini kemudian diberikan perbedaan perlakuan berupa media pembelajaran yang digunakan di dalam kelas. Kelas Eksperimen belajar dengan media google earth sedangkan kelas kontrol belajar dengan media konvensional. Setelah itu kedua kelas diberikan tes akhir berupa instrumen tes kemampuan kognitif yang telah melalui uji kelayakan instrumen sebelumnya. Tujuan penelitian ini adalah untuk mengetahui peningkatan hasil belajar setelah dilakukan pembelajaran dengan menggunakan media google earth.

Tabel 3. Uji Validitas Intrumen

$\begin{array}{llllll}\text { rtabel } & 0.2199 & 0.2199 & 0.2199 & 0.2199 & 0.2199 \\ & 0.2199 & 0.2199 & 0.2199 & 0.2199 & 0.2199 \\ \text { rhitung } & 0.7854 & 0.7976 & 0.8298 & 0.6106 & 0.6003 \\ & 0.6547 & 0.7443 & 0.7306 & 0.7717 & 0.8636 \\ \text { Hasil } & \text { Valid } & \text { Valid } & \text { Valid } & \text { Valid } & \text { Valid } \\ & \text { Valid } & \text { Valid } & \text { Valid } & \text { Valid } & \text { Valid }\end{array}$

Tabel 4. Uji Reliabilitas Reliability Statistics

\begin{tabular}{cc}
\hline Cronbach's Alpha & N of Items \\
.908 & 10 \\
\hline
\end{tabular}

Kriteria Klasifikasi Reliabilitas

$0,800-1,000$ : Sangat Tinggi

$0,600-0,800:$ Tinggi

$0,400-0,600:$ Cukup

$0,200-0,400:$ Rendah

$0,000-0,200:$ Sangat Rendah

Berdasarkan hasil penghitungan menggunakan SPSS diperoleh nilai reliabilitas instrumen yang diujikan sebesar 0,908. Artinya tingkat ketetapan instrumen yang diujikan sangat tinggi.

Analisis data penelitian bertujuan untuk membuktikan kebenaran dari pernyataan yang telah ditetapkan dalam hipotesis penelitian. Data akan dianalisis dengan Uji ANAVA dua jalur, dengan data yang akan dianalisis adalah nilai rata-rata hasil tes kemampuan kognitif siswa kelas eksperimen dan kelas kontrol baik siswa dengan keaktifan rendah maupun siswa dengan keaktifan tinggi.

Sebelum dilakukan uji ANAVA terlebih dahulu dilakukan uji normalitas dan homogenitas data. Uji 
normalitas data dilakukan dengan menggunakan SPSS yakni uji Shapiro-Wilk, dan uji homogenitas data menggunakan uji Levene.

Berikut data hasil pengujian normalitas dan homogenitas data:

Tabel 5. Uji Normalitas Hasil Belajar Siswa Media Google Earth dan Konvensional

\begin{tabular}{lllllllll}
\hline & & \multicolumn{3}{c}{ Kolmogorov-Smirnov $^{\mathrm{a}}$} & \multicolumn{3}{c}{ Shapiro-Wilk } \\
Hasil_Be & Media & Statistic & df & Sig. & Statistic & df & Sig. \\
lajar & $\begin{array}{l}\text { Eoogle } \\
\text { Earth }\end{array}$ & .132 & 39 & .087 & .965 & 39 & .253 \\
& $\begin{array}{l}\text { Konvens } \\
\text { ional }\end{array}$ & .149 & 40 & .026 & .971 & 40 & .391 \\
\hline
\end{tabular}

Dengan menggunakan uji yang sama data siswa media google earth menunjukan hasil seperti pada tabel. Dengan nilai signifikansi 0,253>0,05 menunjukan bahwa data siswa media google earth di kelas ekperimen juga memiliki sebaran data normal atau berdistribusi normal.

Dengan menggunakan uji yang sama data siswa kemampuan media konvensional menunjukan hasil seperti pada tabel. Dengan nilai signifikansi 0,391>0,05 menunjukan bahwa data siswa media konvensional kelas kontrol juga memiliki sebaran normal atau berdistribusi normal.

Dengan demikian dapat dikatakan bahwa data hasil penelitian dari keempat kelompok yang diujikan memiliki sebaran data normal. Sehingga data hasil penelitian dapat dilanjutkan ke tahap uji prasyarat analisis yang berikutnya yakni uji homogenitas data sebelum dilakukan uji hipotesis penelitian menggunakan ANAVA dua jalur.

Tabel 6. Uji Normalitas Hasil Belajar Siswa Keaktifan Rendah dan Tinggi

\begin{tabular}{ccrccccc}
\hline & \multirow{2}{*}{ Keaktifan } & \multicolumn{3}{c}{ Kolmogorov-Smirnov $^{\mathrm{a}}$} & \multicolumn{3}{c}{ Shapiro-Wilk } \\
& & Statistic & Df & Sig. & Statistic & df & Sig. \\
Hasil & Rendah & .110 & 57 & .084 & .979 & 57 & .441 \\
Belajar & Tinggi & .123 & 22 & $.200^{*}$ & .923 & 22 & .088 \\
\hline
\end{tabular}

Data hasil uji shapiro-wilk dikatakan normal jika nilai signifikansi > 0,05. Pada tabel dapat dilihat nilai signifikansi untuk data siswa keaktifan rendah adalah 0,441 $>0,05$. Dapat disimpulkan bahwa data ini memiliki sebaran normal.

Dengan menggunakan uji yang sama data siswa keaktifan tinggi menunjukan hasil seperti pada tabel. Dengan nilai signifikansi 0,088 > 0,05 menunjukan bahwa data siswa keaktifan tinggi juga memiliki sebaran data normal atau berdistribusi normal.

Uji Homogenitas Data

Seperti yang telah disebutkan sebelumnya, uji homogenitas dalam penelitian ini menggunakan uji Levene (Levene's Test). Sama halnya dengan uji ShapiroWilk, Uji
Levene dalam penelitian ini dilakukan dengan bantuan software SPSS.

Tabel 7. Uji Homogenitas Levene's Test of Equality of Error Variances ${ }^{\mathrm{a}}$

\begin{tabular}{cccc}
\multicolumn{4}{c}{$\begin{array}{c}\text { Levene's Test of Equality of Error Variances } \\
\text { Dependent Variable: }\end{array}$} \\
\hline F & Hasil_Belajar & \\
\hline .669 & 3 & df1 2 & Sig. \\
\hline
\end{tabular}

Pasangan hipotesis yang akan diuji adalah sebagai berikut:

$\mathrm{H}_{0}$ : Kelompok sampel berasal dari populasi yang mempunyai varians sama atau homogen

$\mathrm{H}_{1}$ : Kelompok sampel berasal dari populasi yang mempunyai varians berbeda atau tidak homogen

Data hasil uji Levene dikatakan homogen atau $\mathrm{H}_{0}$ diterima jika nilai signifikansi $>0,05$. Uji Levene digunakan untuk menganalisis homogenitas varians yang melibatkan dua kelompok data atau lebih. Dalam penelitian ini uji homogenitas melibatkan empat kelompok data yang berbeda. Kelompok data ini yaitu data siswa kemampuan rendah kelas eksperimen, data siswa kemampuan sedang kelas eksperimen, data siswa kemampuan rendah kelas kontrol, dan data siswa kemampuan sedang kelas kontrol. Pada tabel terlihat angka Levene yang diperoleh nilai signifikansi 0,574>0,05. Sehingga dapat disimpulkan varians data hasil penelitian yang terdiri dari empat kelompok ini homogen.

Data lengkap hasil uji ANAVA dengan bantuan software SPSS dapat dilihat pada bagian lampiran. Data hasil uji ANAVA dua jalur untuk pengujian hipotesis dapat dilihat pada tabel:

Tabel 8. Uji Anava Dua Jalur

Tests of Between-Subjects Effects Dependent Variable: Hasil_Belajar

\begin{tabular}{lrrrrr}
\hline Source & $\begin{array}{c}\text { Type III Sum } \\
\text { of Squares }\end{array}$ & df & Mean Square & \multicolumn{1}{c}{ F } & \multicolumn{1}{c}{ Sig. } \\
Corrected & $1962.978^{\mathrm{a}}$ & 3 & 654.326 & 7.534 & .000 \\
Model & 332463.553 & 1 & 332463.553 & 3827.808 & .000 \\
Intercept & 862.446 & 1 & 862.446 & 9.930 & .002 \\
Media & 470.612 & 1 & 470.612 & 5.418 & .023 \\
Keaktifan & 31.765 & 1 & 31.765 & .366 & .547 \\
Media * & 6514.110 & 75 & 86.855 & & \\
Keaktifan & 456610.000 & 79 & & & \\
Error & 8477.089 & 78 & & & \\
Total & & & & & \\
Corrected & & & & & \\
Total & &
\end{tabular}

Pada tabel terdapat 3 baris yang mewakili hasil uji hipotesis penelitian. Label "media" mewakili hipotesis penelitian pertama, hipotesis terdapat pengaruh media terhadap hasil belajar siswa. Dengan hipotesis deskriptif sebagai berikut: 
$\mathrm{H}_{0}$ : Tidak terdapat pengaruh media pembelajaran terhadap hasil belajar siswa.

$\mathrm{H}_{1}$ : Terdapat pengaruh media pembelajaran terhadap hasil belajar siswa.

Dari tabel dapat kita lihat nilai signifikansi untuk pengaruh media terhadap hasil belajar siswa adalah 0,002 < 0,05. Maka dapat disimpulkan bahwa terdapat pengaruh media pembelajaran terhadap hasil belajar siswa.

Sama halnya dengan pengujian hipotesis yang pertama uji hipotesis kedua juga menggunakan aturan yang sama. Label "Keakifan" terdapat pengaruh keaktifan siswa terhadap hasil belajar siswa. Dengan hipotesis deskriptif sebagai berikut:

$\mathrm{H}_{0}$ : Tidak terdapat pengaruh keaktifan terhadap hasil belajar siswa.

$\mathrm{H}_{1}$ : Terdapat pengaruh keaktifan terhadap hasil belajar siswa.

Hasil pengujian hipotesis dapat diketahui dengan melihat nilai signifikansi yang diperoleh. Apabila nilai signifikansi $<0,05$ maka $\mathrm{H}_{1}$ diterima. Dari tabel dapat kita lihat nilai signifikansi untuk pengaruh keaktifan pembelajaran adalah $0,023<0,05$. Maka dapat disimpulkan bahwa terdapat pengaruh keaktifan siswa terhadap hasil belajar siswa.

Uji selanjutnya adalah uji interaksi antar kedua variabel. Hal ini merupakan bagian dari hipotesis penelitian ketiga. Terdapat pengaruh interaksi antara keaktifan dan media terhadap hasil belajar siswa.

Hipotesis deskriptif penelitian yang ketiga yaitu:

$\mathrm{H}_{0} \quad$ : Tidak terdapat pengaruh interaksi antara keaktifan siswa dan media pembelajaran terhadap hasil belajar siswa.

$\mathrm{H}_{1} \quad$ : Terdapat pengaruh interaksi antara keaktifan siswa dan media pembelajaran terhadap hasil belajar siswa.

Sama dengan dua uji sebelumnya, pada uji hipotesis ketiga ini $\mathrm{H}_{1}$ akan diterima jika nilai signifikansi $<0,05$. Pada tabel dapat kita lihat nilai signifikansi untuk pengaruh interaksi antara media dan keaktifan terhadap hasil belajar siswa sebesar 0,547>0,05. Sehingga dapat kita simpulkan bahwa tidak terdapat pengaruh interaksi antara media dan keaktifan terhadap hasil belajar siswa.

\section{PENUTUP}

Berdasarkan hasil penelitian, maka dapat
disimpulkan bahwa:
Terdapat pengaruh media terhadap hasil belajar
siswa. Dengan uji yang sama yakni uji anava dua jalur
diperoleh nilai signifikansi pengaruh tingkat kemampuan
kognitif sebesar $0,002<0,05$. Hal ini menunjukan terdapat
pengaruh yang signifikan media tehadap hasil belajar

siswa. Dengan hasil, hasil belajar dengan media google earth lebih baik dibandingkan hasil belajar dengan media konvensional.

Terdapat pengaruh keaktifan terhadap hasil belajar siswa. Kesimpulan ini diambil mengacu pada hasil uji empiris menggunakan anava dua jalur. Dengan hasil uji menunjukan nilai signifikansi pengaruh keaktifan terhadap hasil belajar siswa sebesar $0,023<0,05$. Hal ini menunjukan terdapat pengaruh signifikan dari keaktifan terhadap hasil belajar siswa.

Tidak terdapat pengaruh interaksi keaktifan dan media terhadap hasil belajar siswa. Kesimpulan ini diambil berdasarkan hasil uji anava dua jalur yang menunjukan nilai signifikansi pengaruh interaksi keaktifan dan media terhadap hasil belajar siswa sebesar 0,547 > 0,05. Hal ini menunjukkan interaksi antara media dan keaktifan tidak memiliki pengaruh signifikan terhadap hasil belajar siswa.

Berdasarkan kesimpulan seperti yang dipaparkan di atas disarankan hal-hal sebagai berikut:

Dalam pelaksanaan pembelajaran, guru sebaiknya menggunakan aplikasi google earth agar dapat memudahkan guru untuk menyampaikan materi pelajaran khususnya pada indahnya negeriku.

Dalam pelaksanaan pembelajaran, guru sebaiknya memanfaatkan google earth agar dapat meningkatkan aktivitas siswa di kelas.

Bagi peneliti yang ingin meneliti lebih lanjut tentang pengaruh media google earth dengan variabel yang sama diharapkan menggunakan materi yang berbeda sehingga hasil belajar dapat dilihat dari beberapa materi lain yang mempengaruhinya.

\section{DAFTAR PUSTAKA}

Arikunto, Suharsimi. (2013). Dasar-Dasar Evaluasi Pendidikan Edisi 2. Jakarta: Bumi Aksara.

Daryanto. (2010). Media Pembelajaran Peranannya Sangat Penting dalam Mencapai Tujuan Pembelajaran. Yogyajarta: Gava Media

Dimyati \& Mudjiono. (2009). Belajar \& Pembelajaran. Jakarta: Rineka Cipta.

Djamarah, Syaiful Bahri. (2008). Psikologi Belajar. Jakarta: Rineka Cipta.

Hamalik, Oemar. (2011). Kurikulum dan Pembelajaran. Jakarta: Bumi Aksara.

Kadir. (2010). Statistika untuk Penelitian Ilmu-Ilmu Sosial. Jakarta: PT Rosemata Sampurna.

Munadi, Yudhi. (2013). Media Pembelajaran Sebuah Pendekatan Baru. Jakarta: GP. Press Group. 
Munir. (2009). Pembelajaran Jarak Jauh Berbasis Teknologi Informasi dan Komunikasi. Bandung: Alfabeta

Purwanto. (2011). Evaluasi Hasil Belajar. Yogyakarta: Pustaka Pelajar

Sa'ud, Udin Saifudin. (2008). Inovasi pendidikan. Bandung: Alfabeta

Slameto. (2010). Belajar \& Faktor-Faktor yang Mempengaruhinya. Jakarta: Rineka Cipta

Syah, Muhibbin. (2010). Psikologi Pendidikan dengan Pendekatan Baru. Bandung: Rosda

Yamin, Martinis. (2007). Profesionalisasi Guru \& Implementasi KTSP. Jakarta: Gaung Persada Press.

Winarsunu, Tulus. (2009). Statistik dalam Penelitian Psikologi \& Pendidikan. Malang: UMM Press. 